\title{
Ideologies in Markets, Organizations, and Business Ethics: Drafting a Map: Introduction to the Special Issue
}

\author{
Michaela Haase $^{1} \cdot$ Emmanuel Raufflet $^{2}$
}

Received: 28 April 2016/Accepted: 15 August 2016/Published online: 24 August 2016

(C) Springer Science+Business Media Dordrecht 2016

\begin{abstract}
Abbreviations
CSR Corporate social responsibility

HRM Human resource management

EU European Union
\end{abstract}

Interest in corporate social responsibility (CSR) has increased exponentially over the last few decades. Many articles and special issues have been published that define and document the roles and responsibilities of business organizations in different contexts (see, for example, Fleming et al. 2013; Jack et al. 2012; Scherer et al. 2009). CSR has expanded in several fields. First, a significant proportion of the research on CSR has focused on the business organization itself, including organizational motivation, internal processes, implementation challenges, and strategic aspects focused on the integration of CSR or ethics in corporate strategy (Behnam and Rasche 2009; Singer 2010). A second field has focused on the business case for CSR as well as on the alignment of interests between business organizations and stakeholders around so-called win-win solutions (Porter

Guest Editors: Michaela Haase \& Emmanuel Raufflet.

Michaela Haase

michaela.haase@fu-berlin.de;

http://www.wiwiss.fu-berlin.de/marketing

Emmanuel Raufflet

emmanuel.raufflet@hec.ca;

http://www.hec.ca/en/profs/emmanuel.raufflet.html

1 Fachbereich Wirtschaftswissenschaft, Marketing Department, Freie Universität Berlin, Arnimallee11, 14195 Berlin, Germany

2 HEC Montréal, 3000, chemin de la Côte-Sainte-Catherine, Montreal, QC H3T 2A7, Canada and Kramer 2006; Brammer and Millington 2008; Caroll and Shabana 2010; Schreck 2011; Brennan et al. 2014).

However, the 2008 financial crisis demonstrated the impact of ideologies on markets, organizations, society, business, and, more specifically, CSR and business ethics. It became clear that what was presented prima facie as a mere lack of governance, the result of bankers' greed and malfeasance, or the irrationality of the financial markets could not be understood without reference to ideologies and the values or worldviews related to them (Padelford and White 2009; Lusch and Webster 2011; Davies and McGoey 2012). More specifically, this crisis revealed that in this expanding body of CSR literature, insufficient attention has been paid to the role that ideologies play in the way policies and markets are designed and decisions are made, and how corporate actors understand, interpret, and conduct business and CSR. This special issue of the Journal of Business Ethics examines the ties between ideology, markets, CSR, and business ethics. The remainder of our introduction is organized in three sections. The first section aims to map out ideology in terms of ideas and beliefs, on the one hand, and the subjective and objective dimensions of ideology, on the other hand. The second section ties ideology with management research, generally and more specifically CSR/business ethics research, practice, and education. The last section introduces the contributions of the nine articles published in this special issue.

\section{On the Commonalities of and Differences Between Ideology and Knowledge}

The term "ideology" was coined by Antoine L. C. Destutt de Tracy (1754-1836), a French philosopher of enlightenment and director of the Institute de France. As part of 
the enlightenment project, Destutt's intention was to object to the legitimization of knowledge on the basis of religion, metaphysics, or authority. Destutt de Tracy equated "ideology" with "empirically approved knowledge about ideas" and thus provided the term with a positive connotation (Haase et al. 2009). His intent was to map different forms of ideas (ideos) in an organized way (logos) in order to promote an objective and systematic form of knowledge. Thus, knowledge and ideology were viewed as being separate on the basis of empirical evidence and methodical standards.

Based on the works of Cheal (1979), Schmid (1981), and Van Dijk (1998), we approach the meaning of the concept of ideology by broadly understanding ideologies as frameworks of ideas. From the cognitive perspective, ideology relates to ideas or frameworks of ideas, on the one hand, and to beliefs and beliefs systems or worldviews, on the other hand. Both ideas and beliefs are essential for the understanding of ideology and its impact on theory and practice: they drive the development of knowledge and influence business practice. A division between knowledge and ideology that puts knowledge on the bright side and ideology on the dark one is hard to justify. The reasons for the inadequacy of such a division between knowledge and ideology are, first, that ideas and the belief in ideas play a significant role in science (we include all sciences-natural, social, and others-in this statement). With reference to Lakatos's work in the philosophy of science (1978), we argue that ideas are among the constituents of the hard cores of theories, while the scholarly beliefs in these ideas are what drive the empirical development of theories. More or less, all papers in this special issue deal with such ideas: they address, for example, interpretations of business-society interactions (Djelic and Etchanchu 2015; Dey and Lehner 2016); the relationship between employer and employee (Greenwood and Van Buren III 2016); or compare the ideas related to the concepts of tolerance and respect (Lozano and Escrich 2016). A broad, pragmatic concept of theory includes these beliefs and the scholarly practices related to them. Second, the endeavor to change practices or to initiate social movements against prevailing practices must be accompanied by a critical reflection on ideologies. In addition, when criticized, doubted, or even rejected, ideas do not simply disappear into thin air; they tend to be substituted for other ideas based on the perception that the promotion of an alternative and "better" or more "adequate" or more "sophisticated" ideology is required.

Illustrative of this "replacement" process within business ethics is the assessment of the stakeholder approach as being more adequate and fair, or a more "morally tainted" approach, when compared with the shareholder approach. In arguing in favor of their approach, the advocates of the stakeholder approach have contributed to the dissemination of the view that the stakeholder perspective is a more adequate guide for the understanding, design, and conduct of business relationships.

\section{The Subjective and Objective Dimensions of Knowledge and Ideology}

That knowledge and ideology are so close makes distinguishing between them so important. In this regard, it is helpful to consider the subjective and objective dimensions of ideology. We start with the objective dimension: In the same way as knowledge, ideology exists independently of the beliefs of individuals and groups, and ideology can be documented, codified, and described. As mentioned above, ideas are part of the hard cores of theories and, as such, are part of our knowledge embodied in theories, or so-called objective knowledge. However, the objective dimension is not sufficient to characterize ideology. An ideology has an objective dimension that refers to ideas and a subjective dimension that refers to beliefs in ideas. In this vein, an ideology is a Janus-faced entity: one side of its face looks into the world of objective phenomena. In the objective and timeless "world of ideas," ideas are disconnected from their origins and from the concrete individuals who have brought them to the forefront, or have advocated them, or have any other relationship to them. In this vein, ideas are time-independent and mind-independent entities (i.e., objective entities). These objective characteristics make ideology comparable but different to knowledge. In case of ideology, independence from beliefs "guarantees" their "objective existence" in a "world of ideas." However, nobody needs to have belief in these ideas and they thus unfold no impact on social reality. In the case of knowledge, a natural law might be true even if nobody believes in it, and it might be wrong although (close to) everybody believes in its truth. Realistic strands in epistemology believe that the truth of the law is determined by the way the world is, not by what we believe how it is. Basing our understanding of the world on knowledge leads us to believe that the world is as it is, and if we have knowledge about it, then this knowledge is true or false independent of what we believe. However, if we take a closer look at the generation of objective knowledge, we detect methodically backed intersubjective agreement as its origin, not the "real world." As it is impossible to decide on the truth of sentences in the correspondence-theoretical sense, both the extension of subjective judgments from the individual or groups or scientific communities and intersubjectivity are required in order to recognize something as conjectural knowledge in the sense of Popper. In other words, in the case of knowledge, the subjective dimension is harnessed to generate intersubjectivity, which is interpreted as objectivity. 
The other side of the Janus face looks into the world of subjective beliefs, and this world is populated by individual and group beliefs as well. Ideology translates into practices as individuals and groups hold and promote these beliefs through their interactions and practices. Individuals can believe in ideas, or they can trust them, or they can consider them as important-important enough to take action to disseminate, justify, or criticize them, or fight against them. Beliefs are put into action (Da Fonseca 1991) and, in their wake, ideas as well. That and how beliefs are put into action is addressed by the majority of the articles in this volume. "Beliefs in action" have led to, for example, shifting frontiers between economy and polity (Djelic and Etchanchu 2015) and the mobilization of ideologies to prevent the importation of Chinese solar panels to Europe (Kolk and Curran 2015); it sparked activities of social movements (Panayiotis 2016) or social entrepreneurs (Dey and Lehner 2016); coined health reforms in New Zealand (Brunton 2016); or counteracted CSR measures (Bento et al. 2016).

Ideas come into contact with contemporary "social worlds" via partly conscious and partly unconscious mental processes and via the social action taken by individuals or groups. The latter play a particular role in the social process of disseminating ideology. Because ideas are put into action by individuals and groups, ideas can influence the consciousness within groups or even societies and their practices as well. Dey and Lehner (2016) report this in the case of an intermediary organization involved in the creation of meaning for social entrepreneurship. As the articles in this volume are indicative of, scholars play a part in the dissemination of ideology and its influence on practices as well. Lozano and Escrich (2016), for example, argue for the preferableness of the ideology of respect compared with the ideology of tolerance in order to cope with diversity in business; Greenwood and Van Buren III (2016) detail the consequences of unitarism in human resource management (HRM) on the understanding of the employer-employee relationship and favor pluralism in HRM; Martineau et al. (2016) plea for more variety in ethics programs. These scholars aim at bringing about positive consequences of their analysis of ideology. The same can be assumed of the scholars working in the field of CSR. Did they fail and, if the answer is "yes," does this happen because they flagged the wrong ideas? Fleming and Jones' (2013) criticism of "the idea that the logic of neocorporate enterprise might be reformed to consider social issues beyond economic rationality" (Fleming and Jones 2013 , p. 2) may count as an illustration of such a process that has resulted in the "deep conservatism of CSR" (ibid., p. 3) or in CSR practice being frequently shriveled up to a "tokenistic gesture" (ibid.).

\section{Ideologies as Social Phenomena}

As part of the overarching structure of belief systems in a society, ideologies are social phenomena that constitute or inform the mental models of individuals. The effects of ideologies may unfold in an eclipsed or indirect manner; however, individuals can also play an active part in the way they consciously and unconsciously refer to ideologies or allow ideologies to shape their personal belief systems (DiMaggio 2002; for an example, see Becker 2011). Both the personal experiences of individuals and their social intercourse (i.e., the communications between individuals) play a part in this process (Bacon 1902). Durkheim believed that "our basic mental architecture, those "categories of the understanding' [...] were socially acquired" (Bergesen 2004, p. 397; Durkheim 1912).

How human beings (scholars and nonscholars) deal with ideologies depends in part on how they understand and assess them. The Frankfurt School in the philosophy of social science (Habermas) distinguishes between three research programs about ideology: descriptive, pejorative, and positive (Geuss 1981). The relevance of ideology in the study of culture and institutions has been highlighted by scholars from different disciplines (Alverson 1986; Denzau and North 1994; Van Dijk 1998). As compared with knowledge, ideologies raise a claim to truth as well, but are barely open to discussion with other schools of thought. They are seen as solidified certainties, doctrines, or standards, of which the majority of their followers or believers are deeply convinced, resulting in the fact that their basic assumptions or effects are no longer to be questioned. This has added to the negative assessment of ideology by Geuss (1981) in terms of ideology in the pejorative sense. This author, in the tradition of Habermas, elaborates on ideology in the positive sense as well. We think that all three "senses" are important for the understanding of ideology and how we can deal with it.

In a nutshell, the way human beings deal with ideologies is important. Are they critical or uncritical? How do they deal with "rebellious evidence" speaking against their beliefs? A critical stance on all ideas or frameworks of ideas can help to avoid slipping into stances or practices that would be assessed pejoratively. Ideology itself is not the problem, but the issue is with why and how individuals or groups take it into action, assess it, maintain it, disseminate it, etc. Bento et al. (2016) article shows how the ideology expressed in the beliefs of practitioners has thwarted the impact of an incorporation of CSR measures in the balanced scorecard. Although it can be assumed that the ideas undergirding ideologies also have a great impact on the development and application of theories in business, as well as on the emergence of business practices, these 
effects have never been investigated in detail. The articles in this volume are pointing the way ahead.

\section{The Study of Ideologies in Business Ethics and CSR}

The study of ideology within and beyond business ethics and CSR is not new: Ghoshal (2005) has highlighted the relevance of ideology in theory and everyday theory. The former has been addressed in the study of ideas and values that play a part in management or marketing philosophies (e.g., Nowotny 1964; Brown 1999) and the latter in the study of ideas and values that play a part in business philosophies (Jones 1960). Ideologies also influence and shape business education (Ghoshal 2005).

More specifically, business ethics and CSR are academic fields of study that generate knowledge on the basis of ideas regarding the relationship between business and society and the roles that self-interested and/or ethically motivated actors play (and should play) in this regard (Barnett et al. 1994). The age-old debate regarding social responsibility or CSR, which links business to society, as promoted by Bowen (1953) and opposed by the neoclassical view of CSR (Friedman 1962, 1970; Husted and de Jesus Salazar 2006), has been a central feature in the construction of CSR as a field of study (Acquier et al. 2011). However, it has rather seldom been conceived of as a debate on ideologies. Djelic and Etchanchu (2015) put the business-society relationship in historical perspective and show how the perspectives identified by them are ideologically framed. In the next subsection, we list examples of studies in business ethics and CSR related to ideology on different levels of analysis.

\section{Multi-level Analysis of Ideology: Research Questions}

Ideologies have far-reaching impacts on societies and societal institutions on different inter-related levels of analysis:

- On the macro-level, ideology has informed the understandings of the different forms of capitalism (Hall and Soskice 2001; Matten and Moon 2008), which are used in turn to design institutions. These institutions shape the context in which companies operate and the expectations of the relationship between business and society are formed, including interpretations of CSR.

- On the meso-level, ideologies influence the formal and informal structures of markets and marketing systems (Layton 2007, 2009; Haase et al. 2016) and organizations (Thérien 2012), that is, institutional logics (Thornton et al. 2012), industrial and professional associations, cooperation and coordination schemes, and participation and decision-making rules (Chelli and Gendron 2013). Within organizations, ideologies are mobilized to shape ethics and justify internal policies and interactions within organizations.

- On the micro-level, ideologies are part of the belief systems of individuals and exert partly conscious and partly unconscious influences on their decision-making processes. This influence has been discussed in, for example, gender and family studies (for example, Kroska 2002) and has also found expression in business ethics (Forsyth 1980; Barnett et al. 1994; Davis et al. 2001). Furthermore, ideology is used by agents and managers as a strategy to legitimize specific corporate stances and behaviors (Jackall 2010) (Table 1).

Table 1 Illustrations of research addressing the impact of ideology on diverse levels of analysis

\begin{tabular}{|c|c|}
\hline Micro-level approaches & Personal ethical ideologies (Barnett et al. 1994; Forsyth 1980) \\
\hline & $\begin{array}{l}\text { Personal attributes such as religion, gender, age, and other personality variables, including locus of control, } \\
\text { neuroticism, and extroversion (Davis et al. 2001, p. 36) } \\
\text { Antecedents of individual ethical ideologies (Mustamil and Quaddus 2009) }\end{array}$ \\
\hline Meso-level approaches & $\begin{array}{l}\text { Nonclass ties (group affiliations, Merton 1957, p. 465) } \\
\text { Patterned ideologies in the American big business community (Seider 1974, p. 805) } \\
\text { Specific firm ideological development (Seider 1974, p. 805, Fig. 2) } \\
\text { Organizational culture and the ideologies of a company (Durif et al. 2008, p. 64) }\end{array}$ \\
\hline Macro-level approaches & $\begin{array}{l}\text { Business-related paradigms (Goldsby et al. 2006, p. 74) } \\
\text { Sociology of knowledge based on Marx (Seider 1974, p. 803) } \\
\text { General ideological development (Seider } 1974 \text {, p. 804, Fig. 1) }\end{array}$ \\
\hline $\begin{array}{l}\text { Interplay between levels of } \\
\text { analysis }\end{array}$ & $\begin{array}{l}\text { What are the effects of culture on ethical decision making (Vitell et al. 1993)? } \\
\text { What are the relationships between corporate ethical values, religion, and gender and personal ethical ideologies } \\
\text { (Fernando et al. 2008)? } \\
\text { What is the relevance of collectivist cultural values for individual judgment (Parboteeah et al. 2005)? } \\
\text { To what extent can moral insight be considered a social process (Smith and Dubbink 2011, p. 227)? }\end{array}$ \\
\hline
\end{tabular}


Scholars within business ethics and beyond have provided many detailed analyses of ideology related to single levels of analysis; however, more light needs to be shed on their interplay (see Woodbine et al. 2012, p. 211). Empirical studies are required to identify and analyze the social mechanisms (Bunge 1967, 2004; Swedberg and Hedström 1996; Mayntz 2004) that link the different levels of analysis. For example, the study of individual mental models means the study of "input" into social mechanisms, and the study of the dissemination of ideologies means the study of the "output" of social mechanisms. According to Panayiotis (2016), multi-level theory is required to explain the influence of social movements on the origination of corporate social initiatives.

\section{Ideologies in Business Ethics and of Business Ethics}

As applied ethics, business ethics is affected by ideology in a twofold manner: First, its social-scientific constituents do not differ from other disciplines in this regard. Second, its philosophical constituents draw on ideas or frameworks of ideas as well. The key debate on the opposition between the shareholder and the stakeholder approach is an example of this. The shareholder approach is recognized as an ideology (Lazonick and O'Sullivan 2000; Fligstein 2005; Lazonick 2013). This is said mainly by making reference to ideology in the pejorative sense. The "negative" connotation of the concept of ideology is imparted in the field of study or approach that is designated by it simply by the use of the word "ideology." What is the difference between theories as knowledge and theories as ideologies if ideas are part of the hard cores of theories? Should the shareholder approach be rejected because it is an ideology? Is the shareholder approach sufficiently characterized by naming it "an ideology"? What does this mean when it comes to the details? This is a matter of dispute, and different opinions may be justifiable. It seems that the use of the term "ideology" can bring things to an end; however, this is a misunderstanding at best. On the one hand, the formulation "is an ideology" needs specification; on the other hand, what about the approaches that we have called "moral qualities" but that have been characterized as ideology as well (see Freeman 1994)? How can we compare the two ideologies or choose between approaches that include ideas in their hard cores that are not susceptible to or intentionally excluded from empirical proof (Lakatos 1978)?

That business ethics is a discipline not unaffected by ideology means that it does not only study problems accruing from consequences ascribed to pejorative ideology (Lazonick 2013). Ideology in the positive sense plays a part as well. For that reason, we need to ask the fundamental questions about the nature of our discipline: What approaches on the basis of what ideologies do we want to draw on? For example, representatives of Marxist and critical approaches to CSR and business ethics have asked critical questions concerning CSR: Is CSR more just a "tokenistic gesture" or band-aid for the injuries sustained by capitalism (Fleming and Jones 2013, p. 3)? As Fleming and Jones (2013, p. 8) argue, CSR has failed because it never began:

For sure, what might have called external pressure (from, say, social movements, environmental agencies and so-forth) is now transfigured into a business opportunity to deepen the logic of the firm either through legitimization strategies [...] or through socio-political capture, a capitalization on the growing ethos of dissent among consumers, workers and popular culture more generally.

In addition, Silver (2015, p. 280), in his review of Bowie (2013), points out: "This is another clue that business ethics in the twenty-first century, as it is actually practiced, is not really about efficiency or shareholder value; rather, it is an effort that rationalizes a transfer of wealth to those who, in the minds of decision makers, truly deserve it."

We think that the questions asked above cannot be answered if we decide to restrict the analysis of ideology to the pejorative meaning of the concept. As is well-known, the adoption of an approach is a judgment based on values (Velasquez 1996). It is less obvious (or less made public) that it is also a decision pro or contra certain ideas or ideologies. Several articles in this volume plea for or against particular ideologies: Lozano and Escrich (2016) for the ideology of respect; Greenwood and Van Buren III (2016) against unitarism and for pluralism; and Dey and Lehner (2016) against social-entrepreneurship ideology.

\section{Business Ethics Practice and Education}

Business ethics draws on knowledge, both philosophical and empirical. From our perspective, it is an acknowledged academic discipline and education. That notwithstanding the impartment of knowledge about social-scientific phenomena in the domain of business ethics or the discussion of normative knowledge, including principles and values, might not touch upon the beliefs systems of students or future business people to an appreciable amount. Business ethic knowledge may not find expression in business philosophies (Jones 1960). What role does ideology play in the understanding of such possible shortcomings? And what role can it play in overcoming them? The social science perspective in business ethics is strong; the valuable empirical work done is this field is indicative of the presence what Geuss (1981) has called positivistic ideology criticism. Lozano and Escrich (2016) point to a positive role of ideology criticism in business ethics; however, research on what Geuss (1981) called positive ideology is still in its infancy. It is easier for a 
critic to address his or her target in the light of alternatives that two articles in this volume (Greenwood and Van Buren III 2016; Martineau et al. 2016) plea for pluralism is not by chance. Positive ideology criticism needs orientation; it needs to be informed by both moral-philosophical and empirical knowledge. Do we ask the right questions and how can we avoid to get stuck in blind alleys (see Fleming and Jones 2013)?

This special issue does not add to a well-developed body of knowledge in business ethics; it prepares the ground for the development of a new core research topic. We mapped the territory and, with it, a landscape "populated" with many and diverse research opportunities. The conduct of research in this field is both necessary and rewarding. Because of his early death, Sumantra Ghoshal was not able to continue working on the issue of ideology. We are at the beginning of research on ideology in business ethics and CSR, and we hope that this special issue can help to pave the path for studies in business ethics that might be considered as building on some of his ideas and as continuing and extending the field of study.

\section{The Articles}

As one reviewer of one article for this special issue rightly pointed out, "ideology is everywhere." This is reflected in the broadness of the call for papers for this special issue. As we explained in the call for papers, we are interested in the investigation of the links and relationships between the organization-market-society nexus and ideology. We welcomed theoretical and empirical papers from various disciplines related to all levels of analysis and their interactions.

The articles in this special issue are divided in four groups. We begin with theoretical perspectives in business ethics, CSR, and management studies, or at the intersections of these fields, respectively. These articles address the influence of ideology on theoretical perspectives and give reasons for the choice among conflicting perspectives or ideologies. There are three articles in this group. The first article, authored by Marie Laure Djelic and Helen Etchanchu (Contextualizing Corporate Political Responsibilities: Neoliberal CSR in Historical Perspective), puts CSR and its political role in the historical context. The authors argue that contemporary CSR is just one form of business-society interactions that reflect a unique ideological framing. They compare contemporary CSR with two historical ideal types: paternalism in nineteenth century Europe and managerial trusteeship in early twentieth century US. They outline how the political responsibilities of businesses were constructed, negotiated, and practiced in both the cases. This historical contextualization shows that the frontier between economy and polity has always been blurry and shifting, and that firms have played a political role for a very long time. It also shows how the nature, extent, and impact of that political role changed through history and co-evolved with shifts in dominant ideologies.

While Djelic and Etchanchu put the CSR approach into historical perspective, Michelle Greenwood and Harry J. Van Buren III (Ideology in HRM Scholarship: Interrogating the Ideological Performativity of 'New Unitarism') contrast two ideologies having their origin in HRM: unitarism (or new unitarism) and pluralism (or new pluralism). (New) Unitarism dominates HRM scholarship. From the perspective of the authors, this approach reflects the employer perspective in that it aligns the employer and employee interests. Thus, employer ideology has turned into management ideology. The authors begin with an analysis of frames of reference in HRM. They argue "that frames of reference can be both ideological and performative while also serving as epistemic tools communicating various validity claims." After that, building on Habermas, they conduct an epistemic analysis of new unitarism with respect to "claims to power and validity" that can have descriptive, normative, or instrumental orientation. Then, the authors discuss the implications for HRM research, HRM researchers, and the practice of HRM. From their perspective, a "unitarist frame of reference [...] supports a shareholder-centered view of managerial responsibility whilst avoiding the discomfort of believing that doing so requires managers to treat employees instrumentally." Unitarism is limited with respect to its descriptive, normative, and instrumental claims. The authors conclude that an alternative pluralistic frame is more adequate for the understanding of employeremployee relationships, as well as for the taking into account ethical aspects in HRM.

Jose-Felix Lozano and Teresa Escrich (Cultural Diversity in Business: A Critical Reflection on the Ideology of Tolerance) argue that economic change has led to an increase of diversity in businesses. This diversity can be changed into economic opportunity. The authors argue that not only should economic arguments be involved in the study of diversity in businesses but so should ethical arguments. For this reason, Lozano and Escrich inspect ideas related to tolerance and sketch their development. The discussion of tolerance leads them to a point where it becomes obvious that tolerance contains in it ideas that go beyond it and can be discussed under the heading of respect. The integration of business-case thinking and ethics can overcome the limitations of the tolerance-based perspective and can give rise to the emergence of respect. Lozano and Escrich first unfold their understanding of ideology and explain why they relate their research to the 
study of ideology. Then, the authors discuss the concept of tolerance. This discussion spans the time period beginning with the concept's origin and ending with contemporary interpretations. They illuminate the diverse ideas related to the concept of tolerance, connecting it with political and ethical ideologies. However, as the authors point out, it is not only ideas that play a part in the understanding of tolerance but also beliefs in ideas and how these beliefs are put in action. The authors come to the conclusion that the development of ideas subsumed under the ideology of tolerance has led to a new ideology that deserves further attention: the ideology of respect.

The second group of articles focuses on the influence of ideology on public policy. Ans Kolk and Louise Curran's study (Contesting a Place in the Sun? On Ideologies in Foreign Markets and Liabilities of Origin) addresses the controversy around Chinese solar panels in the US and Europe and, with it, "the mobilisation of ideologies in markets and international business" (Kolk and Curran 2015). If technologies whose use can reduce the amount of carbon in the atmosphere are offered at comparatively low costs, does this not harmonize with the objectives of public policy in, for example, Europe? Should it thus not be expected that the importation of these technologies finds support or is promoted by public policy? Based on a casestudy approach, Kolk and Curran examine the role of ideology in attempts to influence public policy and in business representation in the European Union (EU)-China solar panel anti-dumping dispute. In this dispute, the alleged role of the Chinese government was brought to the fore, and a "Chinese threat" was invoked in order to undermine the legitimacy of the Chinese suppliers of solar panels. The study also sheds light on the recent notion of the "liability of origin," in addition to the traditional concept of the "liability of foreignness" that explored in international business research. The case-study analysis illustrates the complexities involved in the interaction between markets and ideologies in the midst of debates regarding different forms of subsidy regimes for renewable energy, free trade versus protectionist tendencies by governments, and the economic and sustainability objectives of firms and societies. It demonstrates how ideology is used to maintain market shares in an EU market, and how the Chinese firms or promoters managed to act counter to these efforts.

While the first article in this group shows how ideology can be instrumentalized for policy issues, the second article addresses a change in public policy and the ideological underpinnings and consequences of this change. Margaret A. Brunton (Rethinking the Sustainability of the Public Health System: Ethical Conundrums and Ideologically Embedded Reform) unveils the outcomes arising from the ideologically driven health reforms that confronted an enduring socialized model of public health care in New Zealand. The article investigates how the change affected the professional identities of junior doctors in New Zealand and their commitment to work. The analysis of an unprecedented strike action of junior doctors in the midst of a reform revealed the tensions between a socialized public healthcare system that privileges cooperation and relies on a public service ethos, espousing the commitment and goodwill of health professionals, with a new public management, market-oriented approach that promotes competitive and self-interested behavior. This article interestingly evidences the links between the macro- and meso-levels of analysis, by which a change in the way the health system is conceived of exerts pressure on the selfunderstanding of junior doctors. The study shows how the implementation of a political reform agenda gives rise to clashes of principles and values; for this reason, political reform should be accompanied by a communication process that makes the changes wished for "visible" to those involved in the process. However, this does not avoid the fact that a system loses resources (e.g., the doctors who choose to quit the system), but it may help keep away from the system those acting on the basis of motifs inadequate for a health care system.

The third group of articles addresses multi-level interactions and social mechanisms. Panayiotis Georgallis (The Link between Social Movements and Corporate Social Initiatives: Towards a Multi-Level Theory) aims to provide a first step toward an integrative theoretical approach to explaining the link between two groups of social phenomena: first, the activities of social movements directed at the initiation or involvement of firms into social initiatives; second, the participation of firms in such initiatives. The article examines social initiatives, the motivations, and results intended, and how ideas (ideologies) influence their belief systems. The article further discusses how can social movements lead firms to engage in such initiatives? In other words, what are the social mechanisms that bring such results about, and what role does ideology play in these mechanisms? According to Georgallis, these mechanisms span phenomena at all levels of analysis and their respective interactions. The study of individual, organizational, and field-level mechanisms is the source of what the author calls multi-level theory. At the field level, the author emphasizes the expectations of key stakeholders; at the organizational level, a corporation's reputation and legitimization are at stake; and at the individual level, the value orientations of the members of the organization and the cognition of the managers are affected by the activities of social movements. In this light, the article understands social movements' activities as "ideologically structured action" that can spark corporate social initiatives. In its conclusion, the article discusses its 
contributions to the debates in the areas of social movement studies, CSR studies, and stakeholder theory. As the author emphasizes, this paper is an invitation for further study of the causal links between the activities of social movements and the propensity of firms to engage in social initiatives using a multi-level theoretical framework and the role played by ideology in this regard.

Pascal Dey and Ottmar Lehner (Registering Ideology in the Creation of Social Entrepreneurs: Intermediary Organizations, "Ideal Subject" and the Promise of Enjoyment) examine the identification of people with social entrepreneurship. Dey and Lehner notice that research on social entrepreneurship has taken an increasing interest in issues pertaining to ideology. Thus, although the authors underline the relevance of ideology in the understanding of social entrepreneurship, they doubt that a singular ideology is at stake. As the authors show, social entrepreneurship is shaped by many ideologies. They argue that the meaning of "social entrepreneurship" does not only draw on scholarly theories but is "created" by intermediary organizations in the field of study as well. The authors conducted a qualitative single-case study of one of these organizations, the Impact Hub, addressing how this organization manages "to establish a relatively coherent, temporarily stable sense of social entrepreneurship as an 'ideal subject' " (Dey and Lehner 2016). The social entrepreneur's commitment to the moral good or the common good is accomplished by a "beatific narrative" "told" to create the belief that the life of the social entrepreneur is both meaningful and enjoyable. The authors highlight that ideology shapes the playing field of business practices: it shapes the "standard way" of doing business, and it shapes what is considered as alternative. In all, Dey and Lehner contend that this "socialentrepreneurship ideology" sits in the way of serious reflections on the contributions of social entrepreneurs to the common good. In their conclusion, Dey and Lehner ask critical questions concerning the constitution of the "ideal subject" in both moral and hedonistic terms. Is a repoliticization of social entrepreneurship required, drawing on ideas originating from ethics and political theory rather than on "empty pleasure" (Dey and Lehner 2016)?

In all, the first and the second papers in this group share the view on the performative role of ideology in playing a part in the social mechanisms that bring social phenomena about. In addition, both articles consider ideology not only as a negative "force" in the social realm, but also as a "positive" force that can bring about the desired change.

The fourth group of articles documents the influence of ideology on organizational decisions and practices in the domain of business ethics. Regina F. Bento, Lasse E. Mertins, and Lourdes F. White (Ideology and the Balanced Scorecard: Am Empirical Exploration of the Tension Between Shareholder Value Maximization and CSR) address the balanced scorecard, whose interpretation ranges from an instrument in organizational accounting to a management system. In any case, the balanced scorecard was an attempt to pay adequate attention to both intangible and physical assets, and it changed the thinking about performance metrics. For this reason, the incorporation of CSR measures in the balanced scorecard is seen or can be seen as a promising step toward the implementation of CSR in an organization's strategy, management, and decision-making process. However, there is no algorithm that steers the reading and assessment of information contained in the balanced scorecard. This information "interacts" with the ideological dispositions of the readers and evaluators. Thus, the presence of CSR measures in a balanced scorecard does not guarantee their impact. In two experiments, the authors investigate "whether CSR is perceived as relevant when financial and CSR measures of managerial performance point in different directions" (Bento et al. 2016). Using a case the authors wrote about a commercial bank, participants were asked to evaluate the performance of two managers. They found that (1) evaluators are more willing to drop CSR performance measures than financial measures from the evaluations; "2) perceived CSR relevance is influenced by where evaluators stand in regard to CSR [...] and also by where evaluators believe shareholders stand (shareholder support); [and] 3) there is a financial bias in appraisal and bonus decisions when CSR measures are used in the balanced scorecard" (Bento et al. 2016). The latter is consistent with shareholder value ideology, as the authors emphasize. The authors show that there are issues to be explored in the practice of evaluators. It is worth mentioning that Bento et al. questioned practitioners who are experienced in accounting. Their article points to the fact that, given the objective to bring about changes in the CSR practices of organizations, it is insufficient to focus on the adaptation of institutions only; instead; the ideologies expressed in the beliefs of practitioners need to be replaced by different ideologies or beliefs.

While the first article in this group shows how ideology can prevent CSR measures from becoming effective in an organization, the second paper advocates for a pluralism of ethics programs as being useful for the improvement of an organization's ethical performance. With regard to the balanced scorecard, the relevance of CSR measures and financial measures were assessed differently, and this result was related to the primacy of shareholder ideology. Compared with the balanced scorecard, ethics programs are not introduced to complete the sources of information addressed in accounting and beyond; they are thought to prevent corporate scandals or to achieve positively assessed consequences of organizational activities, such as integrity, trust, or reputation. As Joé T. Martineau, Kevin J. Johnson, 
and Thierry C. Pauchant (The Pluralist Theory of Ethics Programs Orientations and Ideologies: An Empirical Study Anchored in Requisite Variety) note, ethics programs are usually designed with respect to integrity or compliance. They argue that ethics programs may become infused by dominant logics or ideologies; consequently, a portfolio containing only two orientations may be inferior to a bundle of options. In addition, a list of only two ethics programs runs counter to organizational complexity. There is thus a need for more variety in ethics programs. For this reason, the authors propose what they call a six-orientation model, derived from the literature and empirically validated on the basis of the statistical analysis of responses to an ad hoc questionnaire on organizational ethics practices. The authors identify six different orientations to ethics programs, corresponding to as many types of organizational ethics practices and being complementary and even synergistic rather than in opposition to each other. These authors highlight the links between ideology-related assumptions in business ethics education and the need to foster diversity in designing and delivering ethics courses and curricula.

Both the diversity and the quality of the articles published in this special issue around the diverse facets of ideologies are encouraging signs that the concept is relevant to helping us, both individually and collectively as a community of scholars, go beyond disciplinary silos and enhance the development of more critical, reflexive, and systemic understandings of markets, organizations, society, management, and education. It is our hope that these articles will invite and inspire many more researchers and practitioners in this less traveled direction.

Acknowledgments This special issue is the result of the cooperative efforts of authors, reviewers, the Editors of the Journal of Business Ethics, and the Publishing House. As Guest Editors, we would like to thank all the reviewers who supported this collective learning process in a very diligent and industrious way. We were fortunate to have the support of very dedicated reviewers. We would like to thank all the authors who submitted a paper to this special issue and to the reviewers of all these papers. We learned a lot from all the authors and reviewers, and we feel that their expertise has added to its content and quality. Special thanks go to the Series Editor, Thomas Maak, for taking us "on board" and to Sivakani Jayaprakash for his constant, valuable support throughout the review process. We also thank the Deutsche Forschungsgemeinschaft (DFG), who provided a Cooperation Grant for the research on the topic of this special issue as well as the Direction de la Recherche, HEC Montréal.

\section{References}

Acquier, A., Gond, J.-P., \& Pasquero, J. (2011). Rediscovering Howard R. Bowen's legacy: The unachieved agenda and continuing relevance of social responsibilities of the businessman. Business and Society, 50(4), 607-646.
Alverson, H. (1986). Culture and economy: Games that "play people”. Journal of Economic Issues, 20(3), 661-679.

Bacon, F. (1902). Novum Organum. New York: P. F. Collier and Son.

Barnett, T., Bass, K., \& Brown, G. (1994). Ethical ideology and ethical judgment regarding ethical issues in business. Journal of Business Ethics, 13(6), 469-480.

Becker, G. S. (2011). Economic imperialism. Retrieved July 5, 2011, from http://www.acton.org/pub/religion-liberty/volume-3-num ber-2/economic-imperialism.

Behnam, M., \& Rasche, A. (2009). Are strategists from Mars and ethicists from Venus? Strategizing as ethical reflection. Journal of Business Ethics, 84(1), 79-88.

Bento, R. F., Mertins, L., \& White, L. F. (2016). Ideology and the balanced scorecard: An empirical exploration of the tension between shareholder value maximization and corporate social responsibility. Journal of Business Ethics, . doi:10.1007/s10551016-3053-6.

Bergesen, A. J. (2004). Durkheim's theory of mental categories: A review of the evidence. Annual Review of Sociology, 30(1), 395-408.

Bowen, H. R. (1953). Social responsibilities of the businessman. New York: Harper.

Bowie, N. E. (2013). Business ethics in the 21st century. Dordrecht: Springer.

Brammer, S., \& Millington, A. (2008). Does it pay to be different? An analysis of the relationship between corporate social and financial performance. Strategic Management Journal, 29(12), $1325-1343$.

Brennan, R., Canning, L., \& McDowell, R. (2014). Business-tobusiness marketing (3rd ed.). Los Angeles: Sage.

Brown, S. (1999). Postmodernism: The end of marketing? In D. Brownlie, M. Saren, R. Wensley, \& R. Whittington (Eds.), Rethinking marketing: Towards critical marketing accountings (pp. 27-57). London: Sage.

Brunton, M. A. (2016). Rethinking the sustainability of the public health system: Ethical conundrums and ideologically embedded reform. Journal of Business Ethics,. doi:10.1007/s10551-0163041-x.

Bunge, M. (1967). Scientific research. Studies in the foundations, methodology, and philosophy of science (Vol. 3). Berlin: Springer.

Bunge, M. (2004). How does it work? The search for explanatory mechanism. Philosophy of the Social Sciences, 34(2), 182-210.

Caroll, A. B., \& Shabana, K. M. (2010). The business case for corporate social responsibility: A review of concepts, research and practice. International Journal of Management Reviews, 12(1), 85-105.

Cheal, D. J. (1979). Hegemony, ideology and contradictory consciousness. The Sociological Quarterly, 20(1), 109-117.

Chelli, M., \& Gendron, E. (2013). Sustainability ratings and the disciplinary power of the ideology of numbers. Journal of Business Ethics, 112(2), 187-203.

Da Fonseca, E. G. (1991). Beliefs in action: Economic philosophy and social change. Cambridge: Cambridge University Press.

Davies, W., \& McGoey, L. (2012). Rationalities of ignorance: On financial crisis and the ambivalence of neo-liberal epistemology. Economy and Society, 41(1), 64-83.

Davis, M. A., Anderson, M. G., \& Curtis, M. B. (2001). Measuring ethical ideology in business ethics: A critical analysis of the ethics position questionnaire. Journal of Business Ethics, 32(1), $35-53$.

Denzau, A. T., \& North, D. C. (1994). Shared mental models: Ideologies and institutions. Kyklos, 47(1), 3-31.

Dey, P., \& Lehner, O. (2016). Registering ideology in the creation of social entrepreneurs: Intermediary organizations, "Ideal 
Subject" and the promise of enjoyment. Journal of Business Ethics, doi:10.1007/s10551-016-3112-z.

DiMaggio, P. (2002). Why cognitive (and cultural) sociology needs cognitive psychology. In K. Cerulo (Ed.), Culture in mind: Toward a sociology of culture and cognition (pp. 274-281). New York: Routledge.

Djelic, M., \& Etchanchu, H. (2015). Contextualizing corporate political responsibilities: Neoliberal CSR in historical perspective. Journal of Business Ethics, . doi:10.1007/s10551-015-2879-7.

Durif, F., Graf, R., Hamel, A., Labbe, A., \& Nadeau, A.-M. (2008). Ethics in marketing: Ideology or strategic philanthropy? The case of American apparel. Innovative Marketing, 4(2), 63-69.

Durkheim, E. (1912, 1915). The elementary forms of the religious life. Retrieved April 23, 2013, from http://ia600307.us.archive.org/35/ items/elementaryformso00durk/elementaryformso00durk.pdf.

Fernando, M., Dharmage, S., \& Almeida, S. (2008). Ethical ideologies of senior Australian managers: An empirical study. Journal of Business Ethics, 82(1), 145-155.

Fleming, P., \& Jones, M. T. (2013). The end of corporate social responsibility: Crisis and critique. Los Angeles: Sage.

Fleming, P., Roberts, J., \& Carsten, C. (2013). In search of corporate social responsibility: Introduction to special issue. Organization, 20(3), 337-348.

Fligstein, N. (2005). The end of (shareholder value) ideology? In D. E. Davis (Ed.), Political power and social theory (Vol. 17, pp. 223-228). Bingley: Emerald.

Forsyth, D. R. (1980). A taxonomy of ethical ideologies. Journal of Personality and Social Psychology, 39(1), 175-184.

Freeman, R. E. (1994). The politics of stakeholder theory: Some future directions. Business Ethics Quarterly, 4(4), 409-421.

Friedman, M. (1962). The capitalism of freedom. Chicago: University of Chicago Press.

Friedman, M. (1970). The social responsibility of business is to increase its profits. New York Times Magazine, September 13, 32.

Geuss, R. (1981). The idea of critical theory: Habermas and the Frankfurt School. New York: Cambridge University Press.

Ghoshal, S. (2005). Bad management theories are destroying good management practices. Academy of Management Learning and Education, 4(1), 75-91.

Goldsby, M. G., Burton, B., Grana, P., \& Neck, C. P. (2006). Business ethics versus economics: The ideological foundations of the debate. International Journal of Organizational Analysis, 14(1), 67-83.

Greenwood, M., \& Van Buren, H. J., III. (2016). Ideology in HRM scholarship: Interrogating the ideological performativity of 'New Unitarism'. Journal of Business Ethics,. doi:10.1007/s10551016-3084-z.

Haase, M., Becker, I., Nill, A., Shultz, C. J., \& Gentry, J. W. (2016). Male breadwinner ideology and the inclination to establish market relationships model development using data from Germany and a mixed-methods research strategy. Journal of Macromarketing, 36(2), 149-167.

Haase, M., Roedenbeck, M., \& Söllner, A. (2009). A sketch of a mechanism-based explanation of cognitive path processes, lockin of individual mental models and institutional rigidity. In A. Scherer, I. M. Kaufmann, \& M. Patzer (Eds.), Methoden in der Betriebswirtschaftslehre (pp. 21-46). Wiesbaden: Gabler.

Hall, P. A., \& Soskice, D. (2001). An introduction to varieties of capitalism. In P. A. Hall \& D. Soskice (Eds.), Varieties of capitalism: The institutional foundations of comparative advantage (pp. 1-68). Oxford: Oxford University Press.

Husted, B. W., \& de Jesus Salazar, J. (2006). Taking Friedman seriously: Maximizing profits and social performance. Journal of Management Studies, 43(1), 75-91.

Jack, G., Greenwood, M., \& Schapper, J. (2012). Frontiers, intersections and engagements of ethics and HRM. Journal of Business Ethics, 111(1), 1-12.
Jackall, R. (2010). Moral mazes: The world of corporate managers. Oxford: Oxford University Press.

Jones, M. H. (1960). Evolving a business philosophy. Journal of the Academy of Management, 3(2), 93-98.

Kolk, A. \& Curran, L. (2015). Contesting a place in the sun? On ideologies in foreign markets and liabilities of origin. Journal of Business Ethics. doi:10.1007/s10551-015-2897-5.

Kroska, A. (2002). Does gender ideology matter? Examining the relationship between gender ideology and self- and partnermeaning. Social Psychology Quarterly, 65(3), 248-265.

Lakatos, I., \& Soskice, D. (1978). Falsification and the methodology of scientific research programmes. In J. Worrall \& G. Currie (Eds.), The methodology of scientific research programmes. Philosophical papers (Vol. 1, pp. 8-101). Cambridge: Cambridge University Press.

Layton, R. A. (2007). Marketing systems: A core macromarketing concept. Journal of Macromarketing, 27(3), 227-242.

Layton, R. A. (2009). On economic growth, marketing systems, and the quality of life. Journal of Macromarketing, 29(4), 349-362.

Lazonick, W. (2013). From innovation to financialization: How shareholder value ideology is destroying the US economy. In M. H. Wolfson \& G. A. Epstein (Eds.), The handbook of the political economy of financial crises (pp. 491-511). Oxford: Oxford University Press.

Lazonick, W., \& O’Sullivan, M. (2000). Maximizing shareholder value: A new ideology for corporate governance. Economy and Society, 29(1), 13-35.

Lozano, J.-F., \& Escrich, T. (2016). Cultural diversity in business: A critical reflection on the ideology of tolerance. Journal of Business Ethics, . doi:10.1007/s10551-016-3113-y.

Lusch, R. F., \& Webster, F. E., Jr. (2011). A stakeholder-unifying, cocreation philosophy of marketing. Journal of Macromarketing, 31(2), 129-134.

Martineau, J. T., Johnson, K. J., \& Pauchant, T. C. (2016). The pluralist theory of ethics programs orientations and ideologies: An empirical study anchored in requisite variety. Journal of Business Ethics,. doi:10.1007/s10551-016-3183-x.

Matten, D., \& Moon, J. (2008). "Implicit" and "explicit" CSR: A conceptual framework for a comparative understanding of corporate social responsibility. Academy of Management Review, $33(2), 404-424$.

Mayntz, R. (2004). Mechanisms in the analysis of social macrophenomena. Philosophy of the Social Science, 34(2), 237-259.

Merton, R. K. ([1957] 1968). Social theory and social structure, enlarged edition. Glencoe, IL: Free Press.

Mustamil, N., \& Quaddus, M. (2009). Antecedent factors of ethical ideology in moral judgment: Evidence from the mixed method study. International Journal of Social and Human Sciences, 3, 723-731.

Nowotny, O. H. (1964). American vs. European management philosophy. The International Executive, 6(3), 15-16.

Padelford, W., \& White, D. W. (2009). The shaping of a society's economic ethos: A longitudinal study of individuals' morality of profit-making worldview. Journal of Business Ethics, 85(1), 67-75.

Panayiotis, G. (2016). The link between social movements and corporate social initiatives: Toward a multi-level theory. Journal of Business Ethics, . doi:10.1007/s10551-016-3111-0.

Parboteeah, K. P., Cullen, J. B., Victor, B., \& Sakano, T. (2005). National culture and ethical climates: A comparison of U.S. and Japanese accounting firms. Management International Review, 45(4), 459-481.

Porter, M. E., \& Kramer, M. R. (2006). Strategy and society. Harvard Business Review, 84(12), 78-92.

Scherer, A. G., Palazzo, G., \& Matten, D. (Eds.) (2009). Special issue: The changing role of business in global society: New challenges and responsibilities. Business Ethics Quarterly 19(3), 327-347. 
Schmid, H. (1981). On the origin of ideology. Acta Sociologica, 24(1/ 2), 57-73.

Schreck, P. (2011). Reviewing the business case for corporate social responsibility: New evidence and analysis. Journal of Business Ethics, 103(2), 167-188.

Seider, M. S. (1974). American big business ideology: A context analysis of executive speeches. American Sociological Review, $39(6), 802-815$.

Silver, D. (2015). Business ethics in the 21st century, by Norman E. Bowie. Dordrecht: Springer, 2013. 235 pp. Business Ethics Quarterly, 25(2), 279-282.

Singer, A. E. (2010). Integrating ethics and strategy: A pragmatic approach. Journal of Business Ethics, 92(4), 479-491.

Smith, J., \& Dubbink, W. (2011). Understanding the role of moral principles in business ethics: A Kantian perspective. Business Ethics Quarterly, 21(2), 205-231.

Swedberg, P., \& Hedström, R. (1996). Social mechanisms. Acta Sociologica, 39(3), 281-308.
Thérien, J.-P. (2012). Human security: The making of a UN ideology. Global Society, 26(2), 191-213.

Thornton, P. H., Occasio, W., \& Lounsbury, M. (2012). The institutional logics perspective: A new approach to culture, structure and process. Oxford: Oxford University Press.

Van Dijk, T. A. (1998). Ideology: A multidisciplinary approach. London: Sage.

Velasquez, M. (1996). Business ethics, the social sciences, and moral philosophy. Social Justice Research, 9(1), 97-107.

Vitell, S. J., Nwachukwu, S. L., \& Barnes, J. H. (1993). The effects of culture on ethical decision-making: An application of Hofstede's typology. Journal of Business Ethics, 12(10), 753-760.

Woodbine, G., Fan, H. Y., \& Scully, G. (2012). The ethical orientations of Chinese auditors and the effect on the judgements they make. Asian Journal of Business Ethics, 1(2), 195-216. 